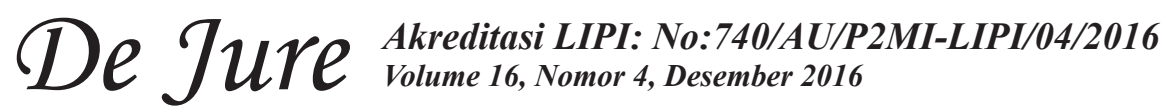

Jurnal Penelitian Hukum De Jure adalah majalah hukum triwulan (Maret, Juni, September dan Desember) diterbitkan oleh Badan Penelitian dan Pengembangan Hukum dan HAM Kementerian Hukum dan HAM RI bekerjasama dengan IKATAN PENELITI HUKUM INDONESIA (IPHI) Pengesahan Badan Hukum Perkumpulan Keputusan Menteri Hukum dan Hak Asasi Manusia Nomor : AHU-13.AHA.01.07 Tahun 2013, Tanggal 28 Januari 2013, bertujuan sebagai wadah dan media komunikasi, serta sarana untuk mempublikasikan aneka permasalahan hukum yang aktual dan terkini bagi para peneliti hukum Indonesia khususnya dan kalangan masyarakat pemerhati hukum pada umumnya.

Penanggung Jawab

Y. Ambeg Paramarta, S.H.,M.Si

(Kepala Badan Penelitian dan Pengembangan Hukum dan Hak Asasi Manusia)

\section{Pemimpin Umum}

Marulak Pardede, S.H.,M.H.,APU

(Ketua Ikatan Peneliti Hukum Indonesia)

\section{Wakil Pemimpin Umum}

T. Daniel L. Tobing, S.H

(Kepala Pusat Pengembangan Data dan Informasi Peneliti Hukum dan Hak Asasi Manusia)

DR. Agus Anwar, S.H.,M.H

(Kepala Pusat Penelitian dan Pengembangan Hukum)

Pemimpin Redaksi

Akhyar Ari Gayo, S.H.,M.H.,APU (Hukum Islam, BALITBANGKUMHAM)

\section{Anggota DewanRedaksi}

DR. Ahmad Ubbe, S.H.,M.H., APU (Hukum Adat, BALITBANGKUMHAM)

Mosgan Situmorang, S.H.,M.H (Hukum Perdata, BALITBANGKUMHAM)

Syprianus Aristieus, S.H.,M.H (Hukum Perusahaan, BALITBANGKUMHAM)

Nevey Varida Ariani, S.H.,M.H (Hukum Pidana, BALITBANGKUMHAM)

Eko Noer Kristiyanto, S.H (Hukum Perdata, BALITBANGKUMHAM)

Muhaimin, S.H (Hukum Islam, BALITBANGKUMHAM)

\section{Redaksi Pelaksana}

Yatun, S.Sos

Sekretaris

M. Virsyah Jayadilaga, S.Si.,M.P

Asmadi

\section{Tata Usaha}

Dra. Evi Djuniarti, M.H

Galuh Hadiningrum, S.H

Suwartono 


\section{TUTe $\begin{aligned} & \text { Akreditasi LIPI: No:740/AU/P2MI-LIPI/04/2016 } \\ & \text { Volume 16, Nomor 4, Desember } 2016\end{aligned}$}

Teknologi Informasi dan Desain Layout

Risma Sari, S.Kom., M.Si (Teknologi Informasi)

Machyudhie, S.T (Teknologi Infornasi)

Saefullah, S.ST.,M.Si (Teknplogi Informasi)

Agus Priyatna, S.Kom (Desain Layout)

Teddy Suryotejo

\section{Mitra Bestari}

Prof. DR. Rianto Adi, M.A (Sosilogi Hukum, UNIKA ATMAJAYA JAKARTA)

Prof. DR. Jeane Neltje Saly, S.H.,M.H (Hukum Humaniter, UNIV. 17 Agustus 1945 Jakarta)

Prof. DR. Hibnu Nugroho, S.H (Hukum Fidana, FH. UNSOED)

DR. Farhana, S.H.,M.H (Hukum Pidana, Fak. Hukum Universitas Islam Jakarta)

DR. Ridwan Nurdin, M.A (Hukum Syariah, Fakultas Syariah Univ. Arraniri Banda Aceh)

DR. Hadi Supratikta (Administrasi Pemerintahan, Balitbang Kemendagri)

\section{Alamat Redaksi:}

Gedung Badan Penelitian dan Pengembangan Hukum dan Hak Asasi Manusia

Kementerian Hukum dan Hak Asasi Manusia Republik Indonesia

Jl. HR. Rasuna Said Kav.4-5, Kuningan, Jakarta Selatan

Telepon, (021)2525015, Faksimili (021) 2526438

Email :

jurnaldejure@yahoo.com

balitbangkumham@gmail.com

ejournaldejure@gmail.com

\section{Percetakan}

PT Pohon Cahaya

Jalan Gedung Baru 18 Jakarta Barat 11440

Telpon (021) 5600111, Faksimili (021) 5670340

Redaksi menerima naskah karya asli yang aktual dalam bidang hukum berupa hasil penelitian dari berbagai kalangan, seperti: peneliti hukum, praktisi dan teoritisi, serta berbagai kalangan lainnya. Tulisan-tulisan yang dimuat merupakan pendapat pribadi penulisnya, bukan pendapat redaksi.

Redaksi berhak menolak, menyingkat naskah tulisan sepanjang tidak mengubah isinya. Naskah tulisan dapat dikirim ke alamat redaksi, maksimum 30 halaman A4, diketik spasi dua rangkap dikirim melalui Email: jurnaldejure@yahoo.com atau melalui aplikasi Open Journal System (OJS) pada URL/website: ejournalbalitbangham.go.id 


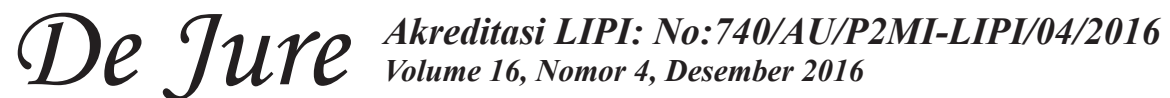

\section{DAFTAR ISI}

\section{DAFTAR ISI}

ADVERTORIAL

Peningkatan Kemampuan Petugas Pemasyarakatan dalam Menangulangi

Peredaran Narkoba di Lembaga Pemasyarakatan dan Rumah Tahanan Negara

(Development of Correctional Officer Competencies In Overcoming Drugs

Trafficking At Correctional Institution And Detention Center)

Nizar Apriansyah

DAFTAR RIWAYAT HIDUP

$505-506$

PEDOMAN PENULISAN

507- 508 



\section{De TuPe $\begin{aligned} & \text { Akreditasi LIPI: No:740/AU/P2MI-LIPI/04/2016 } \\ & \text { Volume 16, Nomor 4, Desember } 2016\end{aligned}$}

Puji syukur kehadirat Allah SWT, Jurnal Penelitian Hukum De Jure yang diterbitkan Badan Penelitian dan Pengembangan Hukum dan HAM Kementerian Hukum dan Hak Asasi Manusia bekerjasama dengan Ikatan Peneliti Hukum Indonesia dapat menerbitkan Volume 16 Nomor 4, Desember 2016.

Para pembaca Jurnal Penelitian Hukum De Jure yang tercinta, sebagaimana diketahui bahwa pada tanggal 10 Desember setiap tahunnya diperingati sebagai Hari Hak Asasi Manusia sedunia. Tanggal ini dipilih untuk menghormat Majelis Umum PBB yang mengadopsi dan memproklamirkan Deklarasi Universal Hak Asasi Manusia, sebuah pernyataan global tentang hak asasi manusia pada 10 Desember 1948.

Apabila menilik Hukum dan HAM, merupakan konsepsi kemanusiaan dan relasi sosial yang dilahirkan dari sejarah peradaban manusia di seluruh penjuru dunia. Hukum dan HAM juga dapat dimaknai sebagai hasil perjuangan manusia untuk mempertahankan dan mencapai harkat kemanusiaannya. Agar HAM dapat ditegakkan dalam berbagai kehidupan harus ada instrumen yang mengaturnya. Instrumen tersebut berisi aturanaturan bagaimana HAM itu ditegakkan dan mengikat seluruh warganegara. Sebagai negara yang menjunjung tinggi HAM Indonesia telah memiliki setidak-tidaknya empat instrumen HAM, yakni UUD 1945, TAP MPR Nomor XVII/MPR/1998, UU Nomor 39 Tahun 1999 tentang Hak Asasi Manusia.

Dari beberapa intrumen yang ada tersebut berharap perlindungan dan penegakan HAM kedepanya dapat meningkat, karena masih banyak kekurangan-kekurangan yang harus diperbaiki oleh pemerintah. Seperti lebih difungsikan secara maksimal lembaga-lembaga yang memiliki tugas khusus menegakan HAM.

Dalam rangka memperingati Hari Hak Asasi Manusia Sedunia tersebut, Dewan Redaksi mengangkat tuisan-tulisan dari para peneliti di lingkungan Kementerian Hukum dan HAM yang bersinggungan dengan penegakan Hukum dan HAM di Indonesia.

Akhirnya kami menyampaikan ucapan terima kasih kepada Kepala Badan Penelitian dan Pengembangan Hukum dan HAM Kementerian Hukum dan HAM RI dan Ketua Ikatan Peneliti Hukum Indonesia dalam penerbitan buku ini. Dan juga kami ucapkan terima kasih kepada Prof. DR. Rianto Adi, M.A., Prof. DR. Jeane Neltje Saly, S.H.,M.H., Prof. DR. Hibnu Nugroho, S.H., DR. Farhana, S.H., M.H., DR. Ridwan Nurdin, M.A.,dan DR. Hadi Supratikta, Selaku Mitra Bestari yang telah bersedia membantu memeriksa dan mengoreksi tulisan dari para penulils.

Jakarta, Desember 2016 



\title{
PENINGKATAN KEMAMPUAN PETUGAS PEMASYARAKATAN \\ DALAM MENANGULANGI PEREDARAN NARKOBA DI LEMBAGA PEMASYARAKATAN DAN RUMAH TAHANAN NEGARA \\ (Development of Correctional Officer Competencies In Overcoming Drugs Trafficking At Correctional Institution And Detention Center)
}

\author{
Nizar Apriansyah \\ Peneliti pada Pusat Pengkajian dan Pengembangan Kebijakan, Badan Penelitian \\ dan Pengembangan Hukum dan Hak Asasi Manusia \\ Kementerian Hukum dan Hak Asasi Manusia Republik Indonesia \\ Jalan HR Rasuna Said Kavling 4 -5, Jakarta Selatan 12920 \\ Telepon (021)2525015 Faksimili (021)2526438 \\ HP: 081385600973 - Email: nizarapriansyah@yahoo.com \\ Tulisan Diterima: 23-12-2016; Direvisi: 1-12-2016; \\ Disetujui diterbitkan: 23-12-2016
}

\begin{abstract}
Problems in correctional institutions sometimes, become a bad highlight by media such as a drug haunt. This research tries to examine a factual data related to drugs trafficking in correctional institution and detention centers. It attempts to find out a pattern of education and training that able to be implemented to educate correctional officers, so that in the future, can be taken steps to anticipate it. It uses quantitative and qualitative approach. Based on discussion, can be concluded that government has already managed to improve correctional officers ‘ abilities by doing interaction between leaders and staffs whose supervision meaning and responsible, have a clear career and promote welfare. (remuneration and correctional allowances). This is one of the government's appreciation (the Ministry of Law and Human Rights) in developing of them in order to boost their performance more optimal. But, some obstacles found in this research such as : the lack of human resources both the alumni of correctional science academy (AKIP) and caretaker/wardens compared to convicts and inmates because the recruitment process of officers did not base on personnel qualification, and lack of infrastructure and facilities.
\end{abstract}

Keywords: correctional officers, drug trafficking

\begin{abstract}
ABSTRAK
Banyaknya permasalahan yang ada Lembaga Pemasyarakatan, menjadi sumber pemeberitaan media yang kerap kali mengimformasikan hal-hal yang negatif tentang lembaga pemasyarakatan dan rumah tahanan sebagai sarang narkoba. Maka dari itu melalui penelitian ini akan berusaha untuk mendapatkan fakta faktual terkait dengan banyaknya kasus peredaran narkoba di Lembaga Pemasyarakatan dan Rumah Tahanan Negara. Dengan maksud untuk mencari tahu pola pendidikan yang dapat diterapkan untuk mendidik petugas pemasyarakatan, agar kedepan dapat diambil langkah-langka strategis di Kementerian Hukum dan Hak Asasi Manusia untuk mengantisipasi hal - hal tersebut.Metode penelitian dengan mengunakan pendekatan kualitatif dan pendekatan kuantitatif. Dari hasil pembahasan menyimpulkan bahwa Pemerintah sudah berusaha meningkatkan kemampuan petugas pemasyarakatan Lembaga Pemasyarakatan dan Rumah Negara dengan cara melakukan interaksi antar pimpinan dan bawahan yang memiliki arti supervisi dan tangung jawab serta kesempatan karier yang jelas. Juga kesejahteraan ekonomi. (seperti Remunerasi dan Tunjangan Pemasyarakatan dan lain-lain). Inilah salah satu bentuk apresiasi pemerintah dalam membina Petugas agar diharapkan kinerjanya lebih optimal dilapangan. Kemudian hambatan diantaranya; kurangnya tenaga teknis pemasyarakaan terutama lulusan Akademi Ilmu Pemasyarakat dan kurangnya tenaga sipir dibandingkan dengan jumlah penghuni serta sumber daya manusia tenaga pemasyarakatan yang masih minim karena sistem perekrutan yang tidak didasari oleh kebutuhan kualifikasi personil, keterbatasan sarana perasana pendukung.
\end{abstract}

Kata Kunci: Petugas Pemasyarakat, Peredaran Narkoba. 


\section{PENDAHULUAN}

Kecenderungan maraknya peredaran narkoba di Lembaga Pemasyarakatan (Lapas) dan Rumah tahanan Negara (Rutan) baik secara kualitas maupun kualitas patut di duga akibat kurangnya keamanan. Hal ini terjadi akibat dari tebatasnya Sarana dan Prasarana pendukung dan kurangnya Sumber Daya Manusia (SDM) di Lapas dan Rutan yang dimiliki, sehingga banyak menimbulkan permasalah- permasalahan. Banyaknya berita - berita yang menyudutkan Lapas dan Rutan sebagai tempat yang aman untuk peredaran Narkoba (http://www.bapanasnews. info/2016/09). Hal tersebut Membuat Menteri Hukum dan HAM, mengeluarkan pernyataan keras. beliau menyatakan tidak main-main dengan program pemberantasan narkoba di Lapas dan Rutan. Bila ada sipir atau petugas di penjara yang terbukti bekerjasama dengan bandar narkoba, akan dipecat.

Memang harus diakui bahwa Lembaga pemasyararakat diharapkan dapat menjadi lembaga pembinaan seperti yang diamanatkan pada Undang-undang Nomor 12 Tahun 1995 Tentang Pemasyarakatan pada pasal 1 ayat 1:

Sistem pemasyarakatan adalah suatu tatanan mengenai arah dan batas serta cara pembinaan warga binaan pemasyarakatan berdasarkan pancasila yang dilaksanakan secara terpadu antara pembina, yang dibina, dan masyarakat untuk meningkatkan kualitas warga binaan pemasyarakatan agar menyadari kesalahan, memperbaiki diri, dan tidak mengulangi tindak pidana sehingga dapat diterima kembali oleh lingkungan masyarakat, dapat aktif berperan dalam pembangunan, dan dapat hidup secara wajar sebagai warga yang baik dan bertanggung jawab.

Untuk mewujudkan hal tersebut diatas Lembaga pemasyarakatan tentu saja banyak sekali mendapat tantangan dan masalah berupa : over capasity di banyak lembaga pemasyarakat di seluruh Indonesia, terbatasnya jumlah personil dan kemampuan SDM petugas yang masih terbatas, serta kurangnya sarana dan prasarana pendukung tugas yang terbatas, (Pusjianbang: 2004) membuat lembaga ini menjadi bulan-bulanan media yang kerap kali mengimformasikan halhal yang negatif tentang lembaga pemasyarakatan dan rumah tahanan sebagai sarang narkoba (http://www.harianhaluan.com: 2012) memang hal ini ada benarnya juga, memang Sulit untuk menepis, peredaran narkoba di Lapas dan Rutan tak terlepas dari adanya keikutsertaan sipir atau petugas di Lapas dan Rutan tersebut di dalam memuluskan peredaran narkoba itu sendiri. Bila sudah demikian, hukuman kurungan di Lapas dan Rutan akhirnya bukan memberikan efek jera terhadap narapidana (napi) kasus narkoba, tapi justru memberikan ruang yang lebih aman bagi orang untuk mengkonsumsi atau pun bertransaksi narkoba.

Begitu mudah dan lancarnya bisnis narkoba di Lapas dan Rutan, tentu ada kekuatan hebat yang berada di belakang jaringan barang haram ini. Secara sederhana, tidak akan mungkin aktivitas para narapidana ini berlangsung lancar dan aman dalam kurun waktu yang cukup lama, jika tidak ada kekuatan yang mem-backup-nya, dan tidak akan mungkin petugas Lapas akan mau bermain-main dengan narkoba serta mengadaikan kredibilitasnya kalau tidak ada imbalan yang setimpal atas perbuatan tersebut. Di sinilah sebenarnya perlu adanya usaha dari pemerintah khususnya jajaran Kementerian Hukum dan HAM dalam membina petugas Lapas dan Rutan dalam mengantisipasi beredarnya narkoba di Lapas dan Rutan seluruh Indonesia bukan sebagai pengedar narkoba di institusinya, di tahun 2015 kurang lebih ada 67 petugas Lapas dan Rutan yang diberhentikan tidak hormat karena terlibat peredaran Narkoba. Dan di tahun 2016 ini sudah ada 3 Orang petugas yang diberhentikan dengan tidak hormat karena terlibat peredaran narkoba di Lapas dan Rutan. (New: http://nasional.republika.co.id.16/03/29/)

Sanksi yang diberikan tehadap petugas lapas dan Rutan yang terbukti mengunakan/memakai dan mengedarkan narkoba tidak membuat petugas sipir penjara menjadi jera terbukti dengan masih banyaknya ditemukan kasus-kasus peredaran Narkoba di lapas dan Rutan, Pendidikan dan pelatihan selama ini diberikan kepada petugas lapas dan Rutan diharapkan dapat membina mental petugas disamping itu pendidikan teknis pemasyarakatan pun diberikan tapi hal tersebut belum membuahkan hasil yang mengembirakan.

Ketika menyaksikan Jakarta Lawyer Club di salah satu televisi swasta nasional yang ditayangkan beberapa waktu yang lalu,(New: http://nasional.republika.co.id.16/03/29/) sempat 


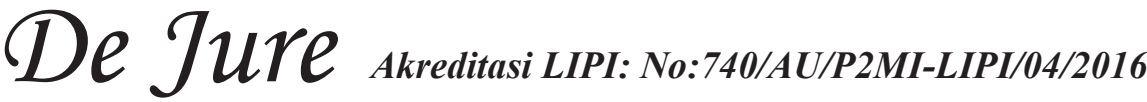

timbul tanda tanya di benak peneliti setelah mendengar berbagai pernyataan, sanggahan dan pertanyaan maupun jawaban dari para narasumber maka dapat penelit simpulkan bahwa setidaknya sekarang ada urgensi untuk segera menyelesaikan berbagai masalah yang ada di lingkungan penjara atau pemasyarakatan. apabila kita amati berbagai permasalahan di Lapas dan Rutan di Indonesia saat ini akan dapat kita klasifikasi sebagai berikut:

\section{1) Over Capacity}

Hampir semua Rutan maupun Lapas di Indonesia mengalami permasalahan yang sama yakni over capacity. Tentunya inilah sumber permasalahan utama yang seharusnya menjadi konsen setiap pejabat di lingkungan Kementerian Hukum dan HAM. Prof. Yusril pernah menyatakan bahwa ketika beliau menjabat sebagai Menteri, mampu membangun beberapa Rutan sebagai upaya mengurangi over capacity dan meningkatkan pelayanan terhadap para tahanan maupun narapidana. Berikut ini kutipan perkataan Yusril yang dimuat oleh Detiknews "Depkeh saat ini anggarannya $\mathrm{Rp} 7,5$ triliun. Saat saya jadi menteri cuma Rp 515 miliar. Tapi saya bisa bikin Rutan Cipinang, Rutan Salemba," -saat-saya-jadi-menkehtunjangan-hakim-sangat-besar. (http://news. detik.com/read/115916/) Sampai saat ini sepanjang yang saya amati belum ada upaya luar biasa yang telah dilakukan oleh jajaran Kemenkumhan hanya sekedar perkataan sedang dilakukan "mapping". Padahal para tahanan dan narapidana sedang menderita dengan berbagai macam kesulitan yang mereka alami di penjara. Memang mereka adalah pelanggar hukum tetapi mereka juga manusia yang memiliki HAM. Dan kegalauan luar biasa juga dialami oleh para petugas pemasyarakatan yang mengawasi kehidupan para tahanan/narapidana. Bayangkan di Jakarta sendiri saja ada 6 lapas Rutan yang semuanya over kapasitas dan bahkan lebih parah daripada di penjara Krobokan Bali. Karena itu harus memulai dan siap untuk menghadapi persoalan-persoalan seperti yang terjadi di Kerobokan Bali.

2). Narapidana/Tahanan Narkoba

Selain masalah over kapasitas juga ada persoalan yang tidak kalah rumitnya yakni tentang peredaran Narkoba di Penjara.
Mengutip perkataan dari Direktur Penindakan dan Pengejaran BNN bahwa permasalahan ini terbagi dua yakni peredaran narkoba di intern penjara dan narapidana/tahanan yang mengendalikan peredaran narkoba di luar penjara. Kita pasti bisa sepakat bahwa permasalahan peredaran narkoba ini terjadi pasti disebabkan karena pengawasan tahanan/narapidana narkoba yang dijadikan satu dengan narapidana/tahanan kriminal umum dalam satu sistem pemenjaraan yang sama. Padahal seharusnya kasus Narkoba mendapat prioritas dalam hal pengawasan. Karena lemahnya pengawasan dan sistem keamanan penjara akan dapat dengan mudah diterobos oleh para pengedar narkoba yang memiliki modal besar. Tidaklah sulit menyelundupkan alat komunikasi, komputer/laptop/tablet dan narkoba kedalam penjara dengan bermodalkan uang hasil bisnis narkoba. Selain itu bercampurnya para pemakai dengan pengedar serta bandar akan menyebabkan permasalahan narkoba di penjara sulit untuk diurai. Dalam hal ini saya juga belum mendengar aksi Denny Indrayana menyelesaikan masalah bercampurnya Narapidana Narkoba dengan Kriminal Umum.

\section{3) Korupsi di Penjara}

Penjara di Indonesia tidak lepas dari perilaku koruptif. ICW telah mengeluarkan hasil riset tentang perilaku koruptif di penjara yakni :

a. Pemberian perlakukan dan fasilitas khusus selama napi dalam tahanan.

Dengan membayar sejumlah uang, seorang napi dapat memperoleh perlakukan atau fasilitas yang berbeda dengan napi yang lain. Napi juga dapat meminta fasilitas khusus misalnya saja sel tersendiri yang terpisah dengan napi lain, mendapatkan makan dan minuman yang bergizi, peralatan elektronik, hiburan dan sebagainya. Jika disepakati bahkan ruangan sel juga dapat disulap menjadi kantor sementara dari napi yang notabene juga seorang pengusaha.

\section{b. Pemberian izin keluar dari penjara}

Napi pada dasarnya memiliki hak keluar dari penjara, misalnya untuk 
berobat atau cuti mengunjungi keluarga. Namun prosedurnya harus ada izin yang diberikan oleh Kepala Lapas dan Kakanwil Departemen Hukum dan HAM. Namun hak-hak tersebut seringkali disimpangkan hanya untuk merasakan kebebasan diluar penjara walau hanya beberapa jam saja.

c. Pemberian pengurangan hukuman (remisi) dan Pembebasan Bersyarat

Pemberian remisi dan pembebasan bersyarat sangat tergantung dari penilaian subyektif kalangan petugas atau kepala penjara. Hal menjadi sangat rentan disalahgunakan dan menjadi komoditas antara oknum petugas dengan napi yang berduit. Akibatnya sering terjadi ketimpangan jumlah remisi antara satu napi dengan napi lainnya. Selain itu proses pembebasan bersyarat yang seharusnya tanpa biaya sekarang bahkan seorang napi harus merogoh koceknya sebesar 3 s/d 5 juta hanya untuk pengurusan pembebasan bersyarat.

d. Pungutan untuk tamu atau pengunjung

Memang sekarang "besuk" atau berkunjung ke penjara tidak dipungut biaya tetapi jangan salah, karena pungutan itu bukan dikenakan pada tamunya tetapi pada napi yang dikunjungi. Napi dipaksa membayar berbagai pungutan disetiap pintu yang dia lewati. Setelah melewati beberapa pintu yang dijaga oleh petugas, dia juga masih harus mengeluarkan uang untuk kepala kamar tempat dia ditempatkan. Apabila ditotal, setiap napi yang dikunjungi harus mengeluarkan uang rata-rata sebesar Rp. 50.000 s/d Rp. 85.000 .

e. Pengunaan narapidana pengganti (stuntman) atau joki narapidana untuk menjalani hukuman.

Yang satu ini mungkin dulu sering dilakukan tetapi sekarang menurut saya akan sulit seiring dengan modernisasi sistem pemasyarakatan dengan menggunakan sistem informasi pemasyarakan yang terintegrasi. Lima modus korupsi diatas tentunya membutuhkan langkah penyelesaian yang komprehensif dan bukan sekedar sidak-sidak yang tidak menyentuh akar permasalahan sesungguhnya. Lima modus koruptif tersebut erat hubungannya dengan SDM Pemasyarakatan yang ada. Dan menurut saya disini juga telah terjadi korupsi yang tidak kalah masif. Apabila kita amati, tidaklah heran jika kita menemukan Bapak-Anak, Kakak-Adik bahkan Bapak-Kakak-Adik yang juga bekerja di lingkungan penjara. Bahkan sebagaian besar petugas pemasyarakatan masih memiliki hubungan family. Tentunya ini merupakan kelemahan terbesar yang patut dicermati. Bagaimana mungkin seorang atasan akan memberikan teguran terhadap anak buahnya apabila orang tua anak buah tersebut adalah atasannya atau seniornya? Bagaimana Pemasyarakan akan memperoleh tenaga SDM yang mumpuni apabila perekrutan pegawainya masih menerapkan sistem perekrutan jaman feodal yang penuh dengan KKN? Kenapa suara bahkan tindakan Menteri dan Wakil Menteri tidak terdengar sama sekali dalam menyelesaikan permasalahan ini? Menurut saya sudah saatnya Menteri dan Wakil Menterinya bekerja secara profesional menyelesaikan akar permasalahan yang menjadikan carut marutnya penjara Indonesia. Profesional dalam arti sebenarnya tanpa mengharapkan pencitraan dan pujian maupun peluang mendapatkan kenaikan jabatan. Sejalan dengan pandangan diatas, bila kita melihat kepada petugas pemasyarakatan, dapat dikatakan bahwa saatinimasih dianggapmemilikikendala tentang pengawasan dan kemampuan yang berkaitan dengan tingkat tangung jawab pelaksanaan fungsi pengamanan, pembiaan dan pembimbingan warga bianaan pemasyarakatan. Hal ini menjadi opini dalammasyarakat, dimana masih mengidentikan lapas dengan penjara masa lampau, juga rendahnya 


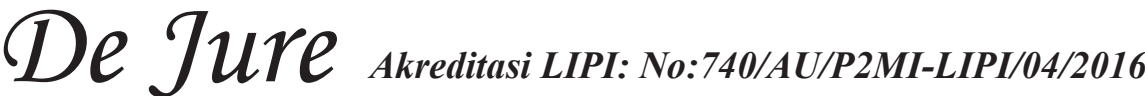

kepercayaan masyarakat. Oleh karena itu sewajarnya petugas pemasyarakatan mendapat perhatian serius perihal pembinaan dan kariernya.

Berdasarkan pengantar dan pernyataan masalah diatas, maka beberapa pertanyaan mendasar diantaranya bagaimana usaha Kementerian Hukum dan Hak Asasi Manusia dalam meningkatkan kemampuan petugas Lapas dan Rutan ?Apa saja upaya Kementerian Hukum dan Hak Asasi Manusia dalam mengantisipasi Peredaran Narkoba di Lapas dan Rutan ?

Adapun tujuan dari penelitian ini untuk mendapatkan fakta faktual terkait dengan banyaknya kasus peredaran narkoba di Lapas dan Rutan. Dimaksudkan untuk mencari tahu pola pendidikan yang dapat diterapkan untuk mendidik petugas pemasyarakatan, agar kedepan dapat diambil langkah-langka strategis di Kementerian Hukum dan Hak Asasi Manusia untuk mengantisipasi hal -hal tersebut.

\section{METODOLOGI PENELITIAN}

Penelitian ini didekati dengan pendekatan kualitatif dan pendekatan kuantitatif. Pendekatan kualitatif dilakukan sebagai strategi untuk mengumpulkan dan memanfaatkan semua data kuantitatif yang terkait dengan pokok permasalahan. Pendekatan kuantitatif dilakukan secara terbatas untuk menganalisa data yang bersifat kuantitatif berupa jumlah dan perhitungan-perhitungan yang terkait dengan pokok permasalahan penelitian.

Penelitian ini bersifat deskripsi spesifik yang akan mengambarkan fenomena peredaran narkoba yang terjadi di lapas dan Rutan seluruh Indonesia Kemudian menganalisa dengan cara mengklasifikasikan data secara spesifik dan membandingkan/menyandingkan dengan aturanaturan yang ada untuk mendapatkan pemecahan masalah utama pada penelitian .

Bentuk penelitian ini adalah evaluatif yang bertujuan untuk melihat tingkat keberhasilan pelaksanaan tugas pokok dan fungsi-fungsi SDM di Pemasyarakatan

Sampel dalam penelitian ini diambil dari keseluruhan kelompok/unit analisis berupa fenomena peredaran narkoba yang terjadi di Lapas dan Rutan, sampel diambil dari data peredaran narkoba yang melibatkan petugas Lapas dan Rutan, serta kerusuhan yang patut di duga di picu ada peredaran narkoba. Kriteria penarikan sampel secara sengaja ini juga mempertimbangan beberapa faktor :

a) Data penyebab kerusushan di Lapas dan Rutan ;

b) Pertimbangan tingkat Pendidikan dan Diklat yang pernah di ikuti oleh Pegawai Lapas dan Rutan.

Data yang digunakan dalam kegiatan penelitian ini adalah data sekunder yang dikumpulkan berdasarkan penelusuran literatur dikumpulkan dari setiap subjek data.

Analisa data dilakukan dengan memeriksa, meneliti data yang telah diperoleh untuk menjamin apakah data dapat dipertanggungjawabkan sesuai dengan kenyataan. Setelah data diolah dan dirasa cukup maka selanjutnya disajikan dalam bentuk narasi Setelah data terkumpul lengkap dan telah diolah dengan menggunakan narasi maka selanjutnya dianalisis secara kualitatif melalui tahap-tahap konseptualisasi, kategorisasi, relasi dan eksplanasi. Konseptualisasi adalah upaya menemukan makna dari konsep-konsep atau dalildalil yang terkandung dalam ketentuan hukum baik yang tertulis maupun. tidak tertulis, melalui interpretasi dari kata-kata atau kalimat-kalimat yang tercantum dalam ketentuan hukum tersebut. Kategorisasi artinya melakukan pengelompokan terhadap konsep-konsep yang sama atau sejenis atau yang berkaitan peredaran narkoba di lapas dan Rutan. Relasi yaitu upaya untuk menghubungkan antara berbagai kategorikategori atau fenomenafenomena yang ada. Eksplanasi yaitu upaya memberikan penjelasan terhadap hubunganhubungan antar berbagai kategori berdasarkan perspektif pemikiran teoritis yang dikemukakan oleh para sarjana atau pakar.

\section{PEMBAHASAN}

\section{A. Unsur-unsur Tindak Pidana}

Menurut ilmu pengetahuan hukum pidana, suatu tindakan itu dapat merupakan "een doen" atau "een niet doen" atau dapat merupakan "hal melakukan sesuatu" ataupun "hal tidak melakukan sesuatu", yang terlahir ini di dalam doktrin juga sering disebut sebagai "een nalaten" yang juga berarti "hal mengalpakan sesuatu yang diwajibkan oleh undang-undang. (Lamintang, 1997:193)

Akan tetapi, "strafbaar feit" itu oleh Hoge Raad juga pernah diartikan bukan sebagai "suatu tindakan" melainkan sebagai suatu peristiwa atau 
sebagai suatu keadaan, dimana seseorang itu harus dipertanggungjawabkan atas timbulnya peristiwaperistiwa atau keadaan-keadaan tersebut tanpa melakukan sesuatu kealpaan atau tanpa adanya orang lain yang telah melakukan suatu kealpaan, sehingga ia harus dipertanggungjawabkan menurut hukum pidana. (Lamintang, 1997:193)

Demikian setiap tindak pidana yang terdapat di dalam KUHP itu pada umumnya dapat kita jabarkan ke dalam unsur-unsur yang pada dasarnya dapat kita bagi menjadi dua macam unsur, yakni unsur-unsur subjektif dan unsur-unsur objektif. Yang dimaksud dengan unsur subjektif adalah unsur-unsur yang melekat pada diri si pelaku atau yang berhubungan dengan diri si pelaku, dan termasuk ke dalamnya yaitu segala sesuatu yang terkandung di dalam hatinya. Sedangkan yang dimaksud dengan unsurobjektifadalahunsur-unsur yang ada hubungannya dengan keadaan-keadaan, yaitu di dalam keadaan-keadaan mana tindakantindakan dari si pelaku itu harus dilakukan.

\section{B. Tinjauan Umum Tentang Narkoba}

Narkoba adalah singkatan dari narkotika dan obat/bahan berbahaya. Selain "narkoba", istilah lain yang diperkenalkan khususnya oleh Departemen Kesehatan Republik Indonesia adalah Napza yang merupakan singkatan dari Narkotika, Psikotropika dan Zat Adiktif. Semua istilah ini, baik "narkoba" ataupun "napza", mengacu pada kelompok senyawa yang umumnya memiliki risiko kecanduan bagi penggunanya.

Menurut pakar kesehatan, narkoba sebenarnya adalah senyawa-senyawa psikotropika yang biasa dipakai untuk membius pasien saat hendak dioperasi atau obat-obatan untuk penyakit tertentu. Namun kini persepsi itu disalahartikan akibat pemakaian di luar peruntukan dan dosis yang semestinya. Perkembangan narkotika dan psikotropika di Indonesia secara historis diawali dengan perkembangan peredaran narkotika yang diatur dalam Verdovende Middelen Ordonnantie (Staatsblad No. 278 jo No. 536). Dalam kehidupan masyarakat, aturan ini lebih dikenal dengan sebutan obat bius. Peraturan perundangundangan ini materi hukumnya hanya mengatur mengenai perdagangan dan penggunaan narkotika, sedangkan tentang pelayanan kesehatan untuk usaha penyembuhan pecandunya tidak diatur. (Siswanto S., 2005:5)

\section{Definisi Narkoba}

Narkoba, sering terdengar beberapa akronim yang berkaitan erat dengan hal tersebut, misalnya: (Hari Sasangka, 2003:4)

1. NAZA (Narkotika dan Zat Adiktif);

2. NAPZA (Narkotika, Alkohol, Psikotropika, dan Zat Adiktif).

NAPZA yang mempunyai arti lebih lengkap dibanding yang pertama, maka obat yang dianggap berbahaya adalah narkotika, alkohol, psikotropika dan zat adiktif. Karena psikotropika dan narkotika digolongkan dalam obat-obat atau zat-zat yang berbahaya bagi kesehatan, maka mengenai produksi, peredaran, penyaluran, penyerahan ekspor dan impor obat-obatan tersebut diatur di dalam undang-undang. Ketentuan yang mengatur narkotika dan psikotropika terdapat dalam :

1. Undang-Undang Nomor 5 Tahun 1997 tentang Psikotropika

2. Undang-Undang Nomor 22 Tahun 1997 Tentang Narkotika, yang selanjutnya diubah menjadi Undang-Undang Nomor 35 Tahun 2009.

Sedangkan Zat Adiktif, disinggung dalam Undang-Undang Nomor 23 Tahun 1992 Tentang Kesehatan. (Hari Sasangka, 2003:4-5)

- Pengertian Narkotika adalah zat atau obat yang berasal dari tanaman atau bukan tanaman baik sitesis maupun semi sintetis yang dapat menyebabkan penurunan atau perubahan kesadaran, hilangnya rasa, mengurangi sampai menghilangkan rasa nyeri dan dapat menimbulkan ketergantungan (Pasal 1 angka 1 UU No. 22/1997).

- Pengertian Psikotropika adalah zat atau obat, baik alamiah maupun sintetis bukan narkotika, yag berkhasiat psikoaktif melalui pengaruh selektif pada susunan saraf pusat yang menyebabkan perubahan khas pada aktivitas mental dan perilaku (Pasal 1 Angka 1 UU No. 5/1997). Sedangkan pengertian Zat Adiktif adalah bahan yang penggunaannya dapat menimbulkan ketergantungan psikis (Pasal 1 angka 12 UU No. 23/1992). (Hari Sasangka, 2003:5)

\section{Peredaran Narkoba}

Dengan adanya perkembangan serta kemajuan ilmu pengetahuan dan teknologi serta pesatnya kemajuan komunikasi adalah merupakan salah satu 


\section{De Jure AkreditasiLLPI: No:740/4U/P2M-LIPIOA42016}

penyebab semakin mudahnya pendistribusian atau peredaran narkoba hingga menjangkau sampai ke wilayah-wilayah terpencil di seluruh Indonesia. (Makarto dkk, 2005:5)

Suatu peredaran narkotika, meliputi setiap kegiatan atau serangkaian kegiatan dalam rangka perdagangan, bukan perdagangan maupun pemindahtanganan untuk kepentingan pelayanan kesehatan dan pengembangan ilmu pengetahuan (Pasal 32). Peredaran narkotika tersebut meliputi penyaluran (Pasal 35 sampai 38) atau penyerahan (Pasal 39 sampai 40). Sedangkan pengertian peredaran gelap narkotika adalah setiap kegiatan atau serangkaian kegiatan yang dilakukan secara tanpa hak dan melawan hukum yang ditetapkan sebagai tindak pidana narkotika (Pasal 1 angka 5). (Sasangka, 2003:182)

\section{Peredaran Narkoba di Lapas}

Berdasarkan pada teori lingkungan bahwa keadaan sosial di sekililing manusia mendukung terjadinya sebuah kejahatan, maka tidak menutup kemungkinan didalam Lapas terdapat peredaran narkoba. Jika di lihat dari keadaan Lapas yang terdiri dari individu- individu yang terdiri dari banyaknya karakteristik pelaku kejahatan serta banyaknyajenis kejahatan itu sendiritidak menutup kemungkinan akan terjadinya peredaran narkoba dikalangan narapidana.(Novianto: 2013:8)

Menurut Walter C Recless terdapat beberapa syarat agar penanggulangan kejahatan yang dilakukan pihak Kepolisian bersama Lapas dapat dikatakan berhasil, yakni jika sistem organisasi Kepolisian (Sarjono : 1984 : 138) telah memiliki sistem organisasi yang baik, dan telah ada pembagaian sistem berdasarkan struktur organisasi. Struktur organisasi ini berjalan dengan baik dengan adanya pembagian kewenangan berdasarkan fungsi di kepolisian guna dapat berkoordinasi langsung dengan Kepala lembaga pemasyarakatan (Kalapas)

\section{Gambaran Umum Lembaga Pemasyarakatan}

Menurut Keputusan Menteri Kehakiman RI Lapas adalah unit pelaksanaan teknis pemasyarakatan yang menampung, membina dan merawat narapidana. Menurut Kamus Besar Bahasa Indonesia lembaga adalah suatu organisasi/badan yang tujuannya melakukan suatu penyelidikan keilmuan/melakukan motif usaha sedangkan pemasyarakatan adalah hal/ tindakan memasyarakatkan (memasukkan kedalam masyarakat, menjadikan sebagai anggota masyarakat). Jadi yang dimaksud dengan Lembaga Pemasyarakatan adalah suatu organisasi/ badan usaha atau wadah untuk menampung kegiatan pembinaan bagi narapidana, baik pembinaan secara fisik maupun pembinaan secara rohani agar dapat hidup normal kembali ke masyarakat.

\section{Jenis dan Klasifikasi lapas}

Jenis pelayanan Lembaga Pemasyarakatan dibagi dengan memperhatikan factor usia dan jenis kelamin.

1. Lembaga Pemasyarakatan Umum. Untuk menampung narapidana pria dewasa yang berusia lebih dari 25 tahun.

2. Lembaga Pemasyarakatan Khusus

a. Lembaga Pemasyarakatan Wanita untuk menampung narapidana Wanita dewasa yang berusia lebih dari 21 tahun atau sudah menikah.

b. Lembaga Pemasyarakatan Pemuda untuk menampung narapidana pemuda yang berusia 18-25 tahun.

c. Lembaga pemasyarakatan Anak terdiri dari Lembaga Pemasyarakatan Anak Pria dan Lembaga Pemasyarakatan Anak Wanita

Klasifikasi pada Lembaga Pemasyarakatan berdasarkan kapasitas, tempat kedudukan dan kegiatan kerja.

a. Lembaga Pemasyarakatan Kelas I

Terletak di Ibukota Propinsi dengan kapasitas lebih dari 500 orang.

b. Lembaga Pemasyarakatan Kelas II A Terletak di Kotamadia/ kabupaten dengan kapasitas 250-500 orang.

c. Lembaga Pemasyarakatan kelas II B Terletak di daerah setingkat Kabupaten, kapasitas kurang dari 250 orang.

Pegawai Pemasyarakatan yang berada di UPT Lapas dan Rutan berjumlah 28.337 Orang sedangkan pegawai yang berada pada Direktorat Jenderal Pemasyarakatan berjumlah 490 orang. Jumlah jabatan struktural yang ada di jajaran Pemasyarakatan berjumlah 4.4927 Jabatan. Unit pelaksana teknis berjumlah 600 terdiri dari lapas kelas I berjumlah 13, lapas Kelas II.B berjumlah 115, Rutan Kelas 1 berjumlah 12 Rutan kelas IIB berjumlah 130, Bapas Kelas I berjumlah 17, Rupbasan Kelas I berjumlah 35, Rumah sakit 1, Laps kelas IIA berjumlah 103, Lapas kelas 
III.berjumlah 22, Rutan Kelas IIA berjumlah 11, cabang Rutan berjumlah 58, Bapas kelas II berjumlah 54 dan Rupbasan Kelas II berjumlah 39. (Ma'mun : Steak Holder Meting : 2016)

\section{Pembinaan Narapidana Narkoba}

Pembinaan terhadap narapidana narkoba tidak dapat disamakan dengan narapidana non narkoba karena mereka mempunyai latar belakang yang berbeda, sebab itu maka dikeluarkan Prosedur tetap perlakuan narapidana resiko tinggi termasuk di dalamnya adalah perlakuan terhadap narapidana narkotika. Dalam protap perlakuan narapidana resiko tinggi disebutkan dalam hal ini adalah narapidana narkotika (Ditjen Pas:Jakarta, 2010: 35)

\section{ANALISIS}

\section{A. Peningkatan Kemampuan Petugas Lapas dan Rutan}

Perkembangan pembaharuan pelaksanaan pencegahan kejahatan (prevention of crame) sebagai upaya penanggulanan tindak pidana dan pemahaman masyarakat tentang hakhak asasi manusia sudah semakin meningkat. Demikian pula dengan upaya pelaksanaan program perlakukan terhadap warga binaan pemasyarakatan juga semakin dituntut sejalan dengan lajunya pembangunan nasional disegala bidang. Oleh karena itu pembinaan terhadap petugas pemasyarakatan perlu mendapat perhatian serius agar pelaksanaan tugasnya memiliki bobot sebagaimana yang diharapkan.

Keamanan dan ketertiban Lembaga Pemasyarakatan dan Rumah Tahanan merupakan pondasi sekaligus alat ukur untuk berhasilnya petugas lapas dan rutan. Parameter yang dapat dijadikan ukuran aman atau tertibnya suatu lapas dan rutan meliputi tingkat pelarian narapidana atau tahanan, perkelahian, unjuk rasa, pemberontakan, perjudian, perdagangan dan penyelundupan barang-barang terlarang (senjata, narkotika, dan obat terlarang lainnya). Oleh karena itu, lapas dan rutan berupaya secara maksimal untuk dapat memantau, mencegah, dan menangkal gangguan kamtib. Sikap dan perilaku petugas yang baik dapat mencegah situasi kehidupan penghuni. Sikap dan perilaku yang baik bisa meminimalisasi tingkat pelarian narapidana/tahanan, dapat memelihara keharmonisan kehidupan dalam lapas dan rutan, dapat menjaga dan memelihara seluruh sarana dan prasarana kantor, dan dapat melaksanakan sistem administrasi. Kamtib yang baik merupakan kewajiban sekaligus tanggung jawab petugas teknis pengamanan.

Motivasi merupakan keadaan dalam pribadi seseorang yang mendorong keinginan individu untuk melakukan kegiatankegiatan tertentu guna mencapai suatu tujuan. (Supardi dan Anwar: 2004: 47) Motivasi yang ada pada seseorang akan mewujudkan suatu perilaku yang diarahkan pada tujuan mencapai sasaran kepuasan. Dorongan untuk bekerja akan menghasilkan suatu imbalan agar terpenuhi kebutuhan yang ada dalam diri orang tersebut. Disiplin yang dimaksud adalah sikap atau tingkah laku seseorang yang mencerminkan tingkat kepatuhan atau ketaatannya pada berbagai ketentuan yang berlaku dan tindakan korektif terhadap pelanggaran atas ketentuan atau standar yang telah ditetapkan. (Sondang,1999: 305)

Secara umum situasi dan kondis lapas dan Rutan di Indonesia tidak kondusif (Penelitian Pusjianbang 2004) untuk melaksanakan tugas pokok dan fungsi yang menjadi beban tugas para sipir penjara ini karena kurangnya dukungan fasilitas serta sumberdaya manusia yang kurang memadai sehingga kurang optimalnya dalam menjalankan tugas. Untuk itu perlu diadakan penilaian tentang kinerjanya. Indikasi dari penilaian ini adalah dengan adanya penurunan secara drastis pencapaian sasaran tugas yang telah ditetapkan (Pusjianbang 2004), misalnya:

(a) kurang memahami sepenuhnya apa yang yang harus dikerjakan apakah sesuai dengan perundangan-undangan dan peraturan yang menjadi landasan operasional dan konseptual sistem pemasyarakatan;

(b) perilaku indisipliner seperti tidak masuk kantor dengan alasan sakit, masuk kantor terlambat, meninggalkan kantor pada jam kerja, menunda penyelesaian pekerjaan, berpakaian dinas tidak sesuai dengan aturan dan lain-lain;

(c) melaksanakan tugas-tugas setelah ada perintah sehingga ada kesan kalau petugas berprakarsa terhadap pekerjaan akan takut salah atau merasa membuang waktu.

Dengan demikian dapat dikatakan bahwa untuk pembinaan petugas pemasyarakatan harus terkandung berbagai elemen, yaitu interaksi antar pimpinan dan bawahan, memiliki 


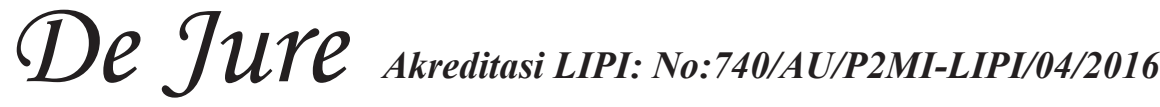

arti supervisi, tangung jawab, kesempatan mengembangkan diri, pengarahan, pengamanan dan pengendalian serta penilaian dan kesempatan meningkatan pengetahuan serta kemampuan yang berkesinambungan. Satu sisi lain elemen penunjang terlaksananya pembinaan adalah melalui pendidikan dan pelatihan bagi pegawai /petugas Lapas dan Rutan. (Panjaitan dan Simorangkir, 1995: 44)

Dalam perjalanannya pembinaan meliputi :

1. pembinaan berupa intruksi langsung yang bersifat kekeluargaan antara yang di bina dan yang membina.

2. pembiaaan yang bersifat persuasive, yang berusaha merubah tingkah laku menjadi keteladanan

3. pembinaan terus-menerus dan sistematis

4. pembinaan keperibadian yang meliputi kesadaran beragama, berbangsa dan bernegara, intelektua, kecerdasan, kesadaran hukum dan keterampilan.

Sedangkan pembinaan karier petugas pemasyarakatan dilingkungan Direktorat Jenderal Pemasyarakatan, Hierarkinya sebagai berikut :

\section{Pelaksanaan Pembinaan Petugas Pemasyarakatan dilaksanakan oleh para pembina yaitu :}

a) Pembinaan Tingkat Pusat, tingkat wilayah dan Tingkat Daerah. Pembiaan Tingkat Pusat adalah Menteri Hukum dan HAM RI dan Dirjen Pemasyarakatan. Pembinaan Tingkat Wilayah adalah kepala Kantor Wilayah sedangkan pembinaan Tingkat Daerah adalah Kepala Unit pelaksana teknis (UPT) Pemasyarakatan.

b) MenteriHukumdanHAMmelaksanakan pembinaan yang bersifat penentuan pemerintah dan pembangunan di bidang hukum. Sedangkan Direktur Jenderal Pemasyarakatan merupakan penjabaran dari kebijakan kementerian Hukum dan HAM

c) Kepala kantor Wilayah Kementerian Hukumdan HAM selaku pembina ditingkat wilayah, melaksanakan program tingkat pusat berdasarkan kewenangan operasional yang meliputi teknis, administratif dan pengawasan dengan cara menerapkan prinsp-prinsip koordinasi, integrasi dan sinkronisas.

d) Kepala Unit Pelaksana Teknis Pemasyarakatan selaku pembina tingkat daerah, melaksanakan sebagian tugas pokok Ditjen Pemasyarakatan

2. Sarana pembianaan Petugas Pemasyarakatan Instrumen yang digunakan sebagai saran pembinaan petugas pemasyarakatan adalah seluruh peraturan perundang-undangan dan kebijakan pimpinan, yang dalam hal ini bersumber dari :

a) Undang-undang Nomor 5 Tahun 2014 tentang Aparatur Sipil Negara.

b) Undang-undang Nomor 8 tahun 1974 tentang kepegawaian beserta perubahan dan peraturan pelaksanaannya;

c) Undang-undang nomor 12 Tahun 1995 tentang Pemasyarakatan beserta peraturan pelaksananya dan;

d) Peraturan perundang-undangan yang lainnya yang berkaitan.

3. Karier Petugas Pemasyaraktan, meliputi:

a) Pengakatan dalam jabatan Struktural

b) Pengangkatan dalam jabatan funsional

c) Kenaikan Pangkat

d) Kenaikan gaji dan tunjangan lainnya;

e) Kesempatan mengikuti pendidikan dan latihan

f) Fasilitas lainnya yang berkaitan dengan kesejahteraan hidup, meliputi ; tempat tinggal, jaminan kesehatan, jaminan keselamatan dalam tugas jaminan hari tua dan asuransi.

\section{B. Upaya dalam mengantisipasi Peredaran Narkoba di Lapas dan Rutan}

Organisasi Lapas berada dalam kontrol Kantor Wilayah Kementerian Hukum dan Hak Asasi Manusia sebagai instansi vertikal. Tercatat jumlah penghuni Lapas mencapai 144.953 penghuni yang tersebar di 442 Lapas, padahal kapasitas Lapas tidak sampai 95 ribu orang, hal tersebut tidak seimbang dengan jumlah pegawai pemasyarakatan yang saat ini berjumlah 28.337 orang. (http://www.kr.co.id/web/2012) Dari jumlah pegawai itu 60 persen merupakan satuan pengamanan lapas dan tahanan. Dan saat ini 
terjadi penumpukan penghuni Lapas di kota-kota besar seperti Jakarta, Surabaya, Makassar, Medan, dan lain sebagainya. Menurut data situs Direktorat Jenderal Lembaga Pemasyarakatan, over capacity terjadi di 29 kantor wilayah dari 33 Kantor Wilayah Kementerian Hukum dan HAM. Artinya, hanya sembilan kanwil yang memiliki Lapas yang cukup untuk menampung penghuni, baik tahanan maupun narapidana.

Struktur organisasi Lapas secara sederhana terdiri atas kepala, sipir, narapidana serta unsur pelengkap seperti petugas kebersihan dan konsumsi. sebenarnya visi Lapas, sudah tentu ingin mengubah perilaku narapidana dari sikap dan perilaku yang kurang baik ke perilaku yang baik dan siap bersosialisasi dengan masyarakat. Namun yang terjadi sebaliknya, terjadi peredaran narkoba, kekerasan dan praktik suap antara petugas dan narapidana untuk memperoleah fasilitas-fasilitas tertentu. Dalam karya klasik James Q Wilson tentang apa dan bagaimana perilaku birokrasi, terdapat suatu analisis perilaku organisasi yang bernama lembaga pemasyarakatan. Organisasi yang bernama Lapas merupakan organisasi publik yang khas dan unik, memiliki visi, misi dan budaya organisasi sesuai dengan jenis anggota yang ada di dalamnya.

Keunikan organisasi Lapas adalah besarnya diskresi yang dimiliki oleh kepala dan sipirnya. Mengapa demikian? Diskresi adalah kewenangan untuk melakukan sesuatu di luar standar dan prosedur yang tertulis. Diskresi lahir dari proses interaksi antara kepala, sipir dan narapidana secara terus menerus, sehingga pada waktu lama membentuk budaya dan menjadi ketentuan hukum internal yang tidak tertulis. Apakah hukum yang tidak tertulis? Misalnya, uang jasa yang harus ada bilamana keluarga napi ingin mengunjungi di luar jam kunjungan atau ingin memperoleh fasilitas di atas standar yang ada. Keunikan kedua adalah budaya anggota organisasi yang lahir didominasi oleh narapidana yang notabene adalah warganegara yang telah dipidana dan sedang menjalani hukuman. Budaya kekerasan, pasar gelap, transaksi suap menyuap mungkin dibawa dari kebiasaan mereka sebelumnya ke dalam Lapas.

Tidak heran jika kita melihat ada napi yang bisa membawa laptop dan punya fasilitas internet untuk melakukan transaksi narkoba di dalam Lapas. Keunikan ketiga adalah indikator keberhasilan yang dipersepsikan oleh para sipir, yakni sejauh mana tidak terjadi keributan atau kekerasan. Indikator ini adalah output dari proses interaksi antara sipir dan narapidana yang berlangsung lama dan dalam suasana penjara yang overload. Tidak mungkin petugas dapat mengontrol semua perilaku napi yang mencapai ribuan. Dari tiga keunikan organisasi Lapas di atas, maka perlu ada pembinaan atau pelatihan khusus kepada para petugas/sipir Lapas dan Rutan di Indonesia.

Kementerian Hukum dan HAM sampai saat ini telah melakukan pembinaan berupa Pendidikan dan Pelatihan (diklat) kepada petugas Lapas dan Rutan seluruh Indonesia berdasarkan data dari Badan Pengembangan dan Sumber Daya Manusia Hukum dan HAM. Khusus untuk petugas lapas sebelum ditempatkan melaksanakan tugas di Lapas dan Rutan terlebih dahulu dididik kesamaptaan di Badan Pengembangan Sumber Daya Manusia Hukum dan HAM serta diklat-diklat lainnya yang bersifat teknis yang dilaksanakan oleh setiap Kanwil di seluruh Indonesia.

Menurut penulis perdasarkan data-data peredaran narkoba di Lapas dan Rutan di Indonesia sebenarnya tidak bisa kita menumpukan kesalahan hanya kepada sipir atau petugas Lapas dan Rutan saja, karena banyaknya jumlah penghuni dan terbatasnya daya tampung menyebabkan kondisi Lapas dan Rutan sendiri menjadi kurang kondusif, disamping itu juga sarana dan prasarana pendukung lainnya yang sangat terbatas akan memungkinkan napi untuk berbuat keonaran atau hal-hal lainnya.

Sudah banyak usaha yang telah dilakukan oleh Kementerian Hukum dan HAM dalam mengantisipasi peredaran narkoba di Lapas dan Rutan seperti baru- baru ini mengadakan tes urine dan terakhir tes narkoba melalui rambut kepada petugas Lapas dan Rutan yang hasilnya dapat diketahui sampai 3 bulan kebelakang bila seseorang teridentifikasi memakai narkoba, melakukan razia terhadap napi yang menggunakan HP di dalam Lapas dan Rutan, memasang CCTV, sampai sidak yang terus dilakukan oleh Dirjen Pas dan Wamen terhadap peredaran narkoba di Lapas dan Rutan. Dan juga ada pembina kedalam berupa pendidikan kesamaptan dan teknis kepada petugas Ring 1 ( Istilah untuk petugas yang bersentuhan langsung dengan para Napi maupun tahanan) serta ada reward and funismen terhadap petugas Lapas dan Rutan. 


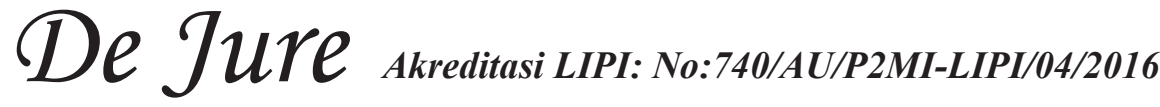

Direktur Jenderal Pemasyarakatan (Dirjenpas) Kemenkumham, Sihabudin, mengatakan,(http://www.jurnas.com/news/57877: 2012) pemberantasan narkoba di dalam penjara bergantung dengan upaya penindakan peredaran narkoba di lingkungan masyarakat. selama masih ada persediaan narkoba di masyarakat, maka peredarannya bisa menjangkau ke dalam rumah tahanan (rutan) dan lembaga pemasyarakatan (lapas). "Masyarakat rutan dan lapas itu miniatur masyarakat di luar. Kalau di luar masih ada supply dan demand, di dalam penjara juga masih banyak karena di dalam kan banyak pemakai. Jika di luar tidak ada, peredaran narkoba didalam juga tidak ada. para pengedar narkoba lebih pintar mengelabui para sipir penjara. modus operandi untuk menyelundupkan narkoba ke dalam rutan atau lapas selalu berubah-ubah dan menggunakan berbagai cara. Misalnya, menggunakan burung merpati pos, pakai ketapel, memakai bola tenis di lempar kedalam lapas. "mengunakan burung merpati pos sebagai kurir, ada juga yang disimpan dalam kulit kacang dan lain-lain, Menurut data dari dirjen pemasyarakatan ada juga pembesuk yang menggunakan cara ekstrim untuk menyelundupkan narkoba. Pembesuk yang berkelamin wanita menyembunyikan narkoba di dalam alat kemaluannya atau berpura-pura sedang menstruasi. Modus seperti ini dua kali terungkap di Lapas Banceuy.

Inilah sekelumit mengapa narkoba susah sekali di berantas di lembaga pemasyarakatan dan rutan di indonesia, karena narkoba ini dikendalikan oleh jaringan yang sudah terorganisir atau transnasional, mudusnya pun berubah- ubah setiap kali ketahuan. Dalam hal ini Kementerian Hukum dan HAM terus berusaha dalam memberanas peredaran Narkoba baik di lapas maupun di rutan sudah banyak sipir atau petugas lapas di pecat karena ketahuan menjadi kaki tanggan agen narkoba di lapas, ini merupakan sok terapi bagi petugas- petugas lain yang coba-coba bermain dengan barang haram ini.

\section{Kendala atau hambatan yang dihadapi}

Sekitar 38 persen dari 147 ribu penghuni lembaga pemasyarakatan (lapas) dan rumah tahanan (rutan) di Indonesia berurusan dengan narkoba. 28.440 petugas yang ada dinilai minim menjadi penyebab masih maraknya peredaraan narkoban di dalam lapas dan rutan."Di dalam lapas dan rutan, para penghuninya jelas-jelas sebagai pelaku pengedar dan pemakai narkoba. Tentu mereka butuh itu, apalagi ketika ada kesempatan untuk mengedarkan dan memakainya," Bila ada angapan bahwa sebanyak 31 ribu petugas lapas dan rutan di seluruh Indonesia melindungi peredaran maupun pemakaian narkoba di dalam lapas dan rutan. Jelas itu bukan perkataan yang bertangung jawab, Penyalahgunaan narkoba disana memang sulit diberantas, karena berbagai faktor, antara lain jumlah petugas yang memang tidak sebanding dengan jumlah penguninya (http://nasional. kompas.com/read/2012/04/04/)

Diakui, sekitar 38 persen dari total 144.953 penghuni lapas dan rutan terlibat narkoba, namun sebagian besar diantara mereka hanya sebagai pemakai. "Seperti dalam 2 tahun terakhir, petugas berhasil menggagagalkan 110 kasus penyeludupan narkoba ke dalam lapas dan rutan. (http:// nasional.kompas.com/read/2012/04/04/) Kendala di internal petugas juga menjadi hambatan dalam memberantas peredaran narkoban di dalam,perlunya penambahan alat untuk pendeteksi ponsel, yang selama ini kebanyakan dipakai sebagai media transaksi narkoba di dalam lapas dan rutan. Pihaknya lapas tidak memiliki alat tersebut dan saat ini hanya pihak Badan Narkotika Nasional (BNN) yang sudah memiliki alat itu. Dan tentu saja harus bekerja sama dengan BNN "Namun permintaan ini tak mulus, karena ada tentangan dari masyarakat di sekitar lapas. Karena akan berpengaruh terhadap jaringan sinyal hp milik masyarakat pula. Upaya lainnya dengan melakukan test riwayat pemakaian narkoba oleh tim pengawas internal lapas/rutan, caranya melalui pemeriksaan rambut. Cara itu dianggap efektif karena bisa mendeteksi pemakaian narkoba dalam 3 bulan terakhir.

Diantara hambatan - atau kendala yang di hadapi oleh sebagian besar Lapas dan Rutan di Indonesia diantara sarana dan prasarana tersebut:

\section{Sarana Gedung Pemasyarakatan}

Gedung Pemasyarakatan merupakan representasi keadaan penghuni di dalamnya. Keadaan gedung yang layak dapat mendukung proses pembinaan yang sesuai harapan. Di Indonesia sendiri, sebagian besar bangunan Lembaga Pemasyarakatan merupakan warisan kolonial, dengan kondisi infrastruktur yang 
terkesan "angker" dan keras. Tembok tinggi yang mengelilingi dengan teralis besi menambah kesan seram penghuninya.

\section{Pembinaan Narapidana}

Bahwa sarana untuk pendidikan keterampilan di Lembaga Pemasyarakatan sangat terbatas, baik dalam jumlahnya maupun dalam jenisnya, dan bahkan ada sarana yang sudah demikian lama sehingga tidak berfungsi lagi, atau kalau toh berfungsi, hasilnya tidak memadai dengan barangbarang yang diproduksikan di luar (hasil produksi perusahan).

\section{Petugas Pembinaan di Lapas}

Sebagian besar dari petugas Lapas dan Rutan belum ditunjang oleh bekal kecakapan melakukan pembinaan dengan pendekatan humanis yang dapat menyentuh perasaan para narapidana, dan mampu berdaya cipta dalam melakukan pembinaan. Pembinaan narapidana di dalam dan di luar lembaga, tak bisa dipisahkan dari kondisi sumber daya petugas yang secara umum tidak cukup kapabel. Hal ini di antaranya disebabkan oleh: Sistem perekrutan yang tidak didasari oleh kebutuhan kualifikasi personil. Lemahnya keterkaitan kurikulum Akademi Ilmu Pemasyarakatan (AKIP) sebagai institusi yang menghasilkan lulusan untuk bekerja pada Lembaga Pemasyarakatan, padahal jumlah mereka sangat signifikan dan menduduki posisi-posisi penting. Kurangnya pengkayaan kemampuan petugas Lapas dan Bapas melalui pelatihan-pelatihan, dan buruknya sistem gaji dan tunjangan pegawai Lapas dan Bapas yang berpengaruh pada kinerja personil dan lembaga. Mekanisme evaluasi kerja dan jenjang karir petugas yang tak jelas dan tranparan. Friksi antar pegawai yang berasal dari AKIP dengan non AKIP, yang dipicu oleh perlakuan yang diskriminatif, merendahkan petugas dari non AKIP. Anggaran dana operasional untuk lembaga yang sangat minim, dan ketika bertemu dengan moralitas pejabat lembaga yang korup, maka kondisi ini menjadi sangat menekan biayabiaya operasional yang semestinya tidak bisa dikurangi. Sudah dana terbatas, semakin terbatas karena dikorup, pengalokasiannya tidak tepat sasaran, dan tidak efisien (adanya pemborosanpemborosan karena melakukan 'tender' tertutup untuk pengadaan barang, makanan untuk operasional lembaga). Dan yang terutama adalah, kesenjangan konsep pemasyarakatan dengan realitas pelaksanaan di lapangan. Adapun usaha- usaha yang dilakukan untuk mengatasi kendalakendala dalam pembinaan narapidana antara lain adalah: Pertama, dalam rangka mengatasi kekurangan sarana pembinaan narapidana dalam bentuk gedung, pemerintah secara berangsurangsur telah merehabilitasi bangunan Lembaga Pemasyarakatan; Kedua, untuk mengatasi kebutuhan di bidang sarana pembinaan ketrampilan Lembaga Pemasyarakatan seringkali mendapatkan bantuan dari pihak pemerintah berupa alat-alat latihan ketrampilan seperti mesin jahit, alat-alat kesenian, pertukangan, dan perbengkelan. Di samping juga mengadakan kerja sama dengan perusahaanperusahaan swasta guna melengkapi kekurangan sarana ketrampilan tersebut; Ketiga, menambah tenaga baru lulusan Akademi Ilmu Pemasyarakatan, serta memberikan kesempatan bagi tenaga yang sudah ada untuk mengikuti kursus-kursus/penataran-penataran tentang pembinaan narapidana yang diselenggarakan Kementerian Hukum dan HAM ataupun Direktorat Jenderal Pemasyarakatan. Di sisi lain, budaya organisasi dan lingkungan kerja di Lapas juga dapat mempengaruhi bagaimana kinerja petugas Lapas dalam berperan sebagai Petugas pembinaan. Dalam hal ini, budaya organisasi dapat dilihat dari kemampuan tehnik petugas, kerjasama tim (team work), dan potensi kepribadian yang dimiliki oleh petugas dalam menjalankan fungsi dan tanggung jawab khususnya dalam pembinaan narapidana. Dalam hal potensi kepribadian petugas ini, dimaksudkan pada tingkat pemahaman dimensi struktural dan pemahaman dimensi interaksional petugas. Pemahaman dimensi struktural adalah suatu keadaan dimana petugas pembina memiliki informasi yang cukup tentang apa yang menjadi tugas, batas-batas wewenangnya, tanggung jawabnya, hak-haknya, sifat pekerjaannya dan sebagainya. Sedangkan pemahaman dimensi interaksional adalah suatu keadaan dimana petugas pembina dalam hal penerimaan tugas memiliki kemampuan pendidikan dan pengalaman yang cukup dan mampu menghadapi hambatan dalam tugas. Dengan memadainya tingkat pemahaman dimensi struktural dan dimensi interaksinal petugas otomatis peran aktifnya sebagai petugas pembina para narapidana di Lapas dapat lebih berhasil guna dan tepat sasaran. Dengan dikeluarkanya Undang-Undang Nomor 12 Tahun 1995 Tentang Pemasyarakatan. Diharapkan peran lembaga pemasyarakatan lebih optimal bukan sebagai 


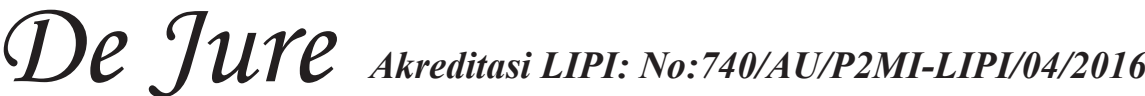

sarang narkoba seperti yang sering diberitakan di koran-koran ataupun TV (data Penelitian)

\section{KESIMPULAN}

Kementerian Hukum dan HAM sudah berusaha meningkatkan kemampuan petugas pemasyarakatan (Lapas dan Rutan) dengan cara melakukan interaksi antar pimpinan dan bawahan yang memiliki arti supervisi dan tangung jawab, kesempatan mengembangkan diri, pengarahan yang terus dilakukan oleh pimpinan, mengarakan petugas untuk selalu memagari diri dengan pengamanan dan pengendalian diri serta diberi kesempatan untuk peningkatan pengetahuan dan kemampuan yang berkesinambungan. Satu sisi lain elemen penunjang terlaksananya pembinaan adalah melalui pendidikan dan pelatihan bagi pegawai petugas Lapas dan Rutan, dengan berbagai cara diantaranya pembinaan berupa intruksi langsung yang bersifat kekeluargaan antara yang di bina dan yang membina, pembiaaan yang bersifat persuasive, yang berusaha merubah tingkah laku menjadi keteladanan, pembinaan terus-menerus dan sistematis serta pembinaan keperibadian yang meliputi kesadaran beragama, berbangsa dan bernegara, intelektual, kecerdasan, kesadaran hukum dan keterampilan. Serta kesempatan karier yang jelas. Juga kesejahteraan ekonomi. (seperti Remunerasi dan Tunjangan Pemasyarakatan dan lain-lain). Inilah salah satu bentuk apresiasi usaha pemerintah dalam membina Petugas Lembaga Pemasyarakatan dan Rutan agar diharapkan kinerjanya lebih optimal dilapangan. Disisi lain juga dengan memberikan Riward bagi petugas yang berprestasi dan memberikan funisment (hukuman bagi petugas yang melakukan kesalahan. Dalam perkembangananya sudah banyak petugas LAPAS dan Rutan yang di pecat karena berani bermain-main dengan Narkoba, dan sudah banyak modus penyelundupan narkoba di LAPAS dan Rutan yang di ketahui dan tertangkap, tapi ini sebenarnya hanya sebagian kecil yang terungkap, sebenarnya masih banyak narkoba yang tidak ketahuan beredar di LAPAS dan Rutan karena setiap kali ketahun mereka (pengedar) selalu mengunakan cara lain. sudah banyak antisipasi yang dilakukan oleh Kementerian Hukum dan HAM dalam menangulagi peredaran narkoba di Lapas dan Rutan diantaranya tes Urine, tes rambut memasang CCTV, alat deteksi HP, dan Rahasia HP
Kendala atau hambatan yang dialami oleh Kementerian Hukum dan HAM terutama Direktorat Jenderal Pemasyarakatan seperti terungkap hambatan tersebut berupa : kurangnya tenaga teknis pemasyarakaan terutama lulusan AKIP (Akademi Ilmu Pemasyarakat) dan kurangnya tenaga sipir dibandingkan dengan jumlah penghuni, serta SDM tenaga Pemasyarakatan yang masih minim karena sistem perekrutan yang tidak didasari oleh kebutuhan kualifikasi personil, keterbatasan sarana dan perasana seperti terbatasnya Senjata Api, borgol yang dimiliki oleh lapas dan rutan serta belum adanya alat pemantau pendukung CCTV (hanya Lapas dan Rutan tertentu saja yang mempunyai CCTV)

\section{SARAN}

Pihak Kemenenterian Hukum dan HAM Cq Direktorat Jenderal Pemasyarakatan hendaknya meningkatkankemampuanpetugasLapasdanRutan dengan cara melakukan pendidikan kesamapataan dan teknis pemasyarakatan sebelum ditempatkan di Lapas dan Rutan. tentu saja hal ini belum cukup, untuk membentengi petugas perlu juga dilakukan pendidikan khusus yang menyangkut ahlak dan lebih ditanamkan lagi rasa tangung jawab terhadap tugas. Kedepannya diharapakan untuk rekrutmen petugas pemasyarakatan di pilih dari putra-putri terbaik dengan cara perekrutan yang teransparan jelas, bertangung jawab, serta memiliki kualifikasi yang baik dan didik secara khusus. Kemudian untuk petugas yang masih berani mengedarkan narkoba, mempasilitasi dan memakai diberikan sangsi yang tegas berupa pemecatan dan sangsi hukum lainnya. Kepada petugas yang berprestasi diberikan riward berupa kenaikan pangkat istimewa dan promosi.

Kepada Kementerian Hukum dan HAM tetap terus melakukan antisipasi peredaran narkoba dilapas dan Rutan secara, Internal dengan melakukan roling terhadap petugas setiap 2 tahun, melakukan tes narkoba secara mendadak kepada setiap petugas dan narapidana, Penambahan saranan dan Prasarana keamanan (pemasangan CCTV, alat mengindai jaringan HP dll), penambahan Lapas baru untuk menganti sipasi over kapasitas, ditambahkan Lapas narkotika di setiap kota propinsi dan penghuninya di silang( diacak untuk memutus jaringan) 


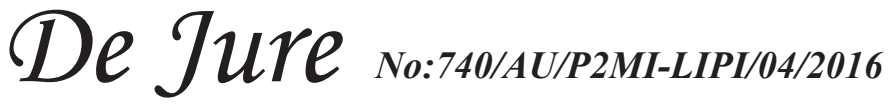

Perlunya upgrading anggota aparat dalam setiap lembaga tidak hanya aparat dari Lembaga Pemasyarakatan, melainkan setiap lembaga seperti Kepolisian. Upgrading ini bertujuan agar adanya bimbingan dan pembinaan setiap oknum supaya mempunyai mental yang baik dalam mengemban wewenang dan tugas di setiap instansi terkait. Serta membentuk akreditasi yang baik pula di mata masyarakat. 


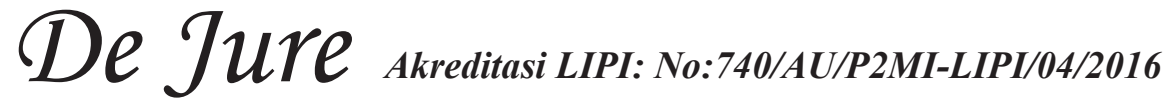

\section{DAFTAR KEPUSTAKAAN}

\section{Buku}

Hari Sasangka. Narkotika dan Psikotropika dalam Hukum Pidana. CV. Mandar Maju. Bandung, 2003

Lamintang, P.A.F. Dasar-dasar Hukum Pidana Indonesia. Citra Aditya Bakti, Bandung, 1997.

Muh. Taufik Makarto, dkk. Tindak Pidana Narkotika. Ghalia Indonesia, Jakarta 2005.

Petrus Irwan Panjaitan dan Pandapotan Simorangkir, Lembaga Pemasyarakatan Dalam Perspektif Sistem Peradilan Pidana, Pustaka Sinar Harapan, Jakarta, 1995.

Sondang Siagian P. Manajemen Sumber Daya Manusia. Bumi Aksara. Jakarta,

Siswanto Sunarsono. Penegakan Hukum Psikotropika dalam Kajian Sosiologi Hukum. PT. Raja Grafindo Persada. Jakarta, 2005.

Supardi dan Anwar, Saiful. Dasar-dasar Perilaku Organisasi. Yogyakarta: UII Press. 2004.

Direktorat Jenderal Pemasyarakatan, Prosedur Tetap Perlakuan Narapidana Resiko Tinggi Jakarta : 2010.

\section{Hasil Penelitian}

Pusat Penelitian dan Pengembangan Departemen Hukum dan HAM tahun 2004. penelitian: Evaluasi System Pemasyarakatan Tahap II Sub system Keamanan dan Ketertiban di Lembaga Pemasyarakatan dan Rumah Tahanan Negara

\section{Internet}

http://www.solopos.com/2012/

http://www.harianhaluan.com

http://www.jejaknews.com. Diakses hari selasa, Indonesia Lawyer club.

http://news.detik.com/read/115916/1869076/10/ yusril.

http://www.beritasatu.com/politik/40858kriminolog-peredaran-narkoba-di-lapasmasalah-akut.

http://www.kr.co.id/web/ Mempertanyakan Efektivitas Sidak Wamenkumham. http://www.jurnas.com/news/57877

h t t p : / / n a s i o n a 1 . k o m pa s. c o m / $\mathrm{read} / 2012 / 04 / 04 / 17585777 /$ Lapas.Sering. Jadi.Tempat.Sindikat. Narkotika

\section{Undang-Undang dan peraturan Perundang Undangan}

Republik Indonesia, Undang-Undang tentang Pemasyarakatan, UU Nomor 12 Tahun 1995

Republik Indonesia, Undang-Undang tentang Budi Daya Tanaman. UU Nomor 12 tahun 1995

Republik Indonesia Undang-Undang Tentang Psikotropika. UU Nomor 5 tahun 1997

Republik Indonesia, Undang-Undang Tentang Aparatur Sipil Negara. UU Nomor 5 Tahun 2014

Republik Indonesia, Peraturan Pemerintah Tentang Perubahan Kedua Atas Peraturan Pemerintah Nomor 32 Tahun 1999 Tentang Syarat Dan Tata Cara Pelaksanaan Hak Warga Binaan Pemasyarakatan, PP Nomor 99 Tahun 2012. 


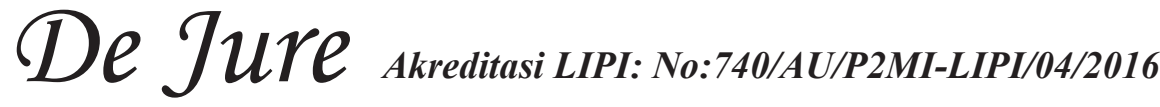

\section{BIODATA PENULIS}

Nama, Nizar Apriansyah, S.E., M.H., Lahir di Muara Enim 1973, memulai karir sebagai Pegawai Negeri Sipil pada tahun 2001 sebagai staf Bidang Program pada Pusat Pengkajian dan Pengembangan Kebijakan. Menyelesaikan Strata 1 Ekonomi Jurusan Manajemen pada Universiatas Tridinanti Palembang pada Tahun 1998. dan melanjutkan kembali ke jenjang pendidikan Strata 2 program Studi Hukum Bisnis di Universitas Pancasila selesai tahun 2015. Karir sebagai peneliti dimulai pada tahun 2008. Saat ini menjabat sebagai Peneliti Madya IV.a. Menulis di Jurnal Widya Riset Lembaga Ilmu Pengetahuan Indonesia (LIPI) dan Jurnal Kebijakan Hukum Kementerian Hukum dan HAM Alamat Rumah Jalan Swadaya 2 Sukatani - Tapos - Depok ; Alamat Kantor Pusat Pengkajian dan Pengembangan Kebijakan (Pusjianbang) Jalan H.R Rasuna Said Kavling 4 -5, Jakarta Selatan 12920 Jakarta Selatan. HP : 081385600973, e-mail : nizarapriansyah@yahoo.com 


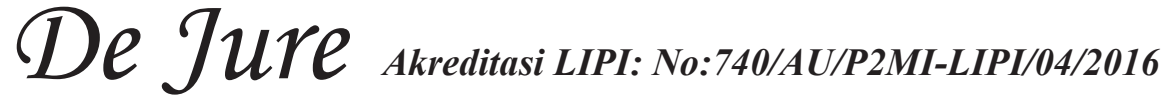

\section{PEDOMAN PENULISAN NASKAH JURNAL PENELITIAN HUKUM DE JURE}

1. Naskah yang dimuat dalam Jurnal Penelitian Hukum De Jure adalah tulisan yang belum pernah dipublikasikan dalam media massa.

2. Naskah yang dimuat dalam Jurnal Penelitian Hukum De Jure meliputi tulisan tentang hasil penelitian (penelitian empiris maupun penelitian normatif atau studi dokumenter), pemikiran dan informasi lain yang bersifat ilmiah.

3. Menggunakan bahasa Indonesia yang baku.

4. Sistimatika Penulisan :

A. Naskah artikel hasil penelitian empiris :

o Judul aktual

Menggambarkan isi naskah dan maksimal 14 kata ditulis dalam bahasa Indonesia dan Inggris

o Nama penulis

Tanpa gelar akademik, jabatan, kepangkatan, alamat lembaga/instansi dan e-mail

o Abstrak

Berisi Latar Belakang, Rumusan Masalah, Tujuan, Kegunaan, Metode, Isi

Pembahasan, Analisis, Kesimpulan dan Saran Temuan ditulis dalam satu spasi;

150 kata (10-20 baris/ satu (1) paragraf) diketik menggunakan huruf Times New

Roman; font 11 italic; ditulis dalam bahasa Indonesia dan bahasa Inggris.

o Kata Kunci

Mengandung yang di indekskan ditulis dalam bahasa Indonesia dan Inggris

dengan minimal 3 kata maksimal 5 kata

- PENDAHULUAN

Berisi latar belakang masalah dan rumusan masalah, tujuan, kegunaan, kerangka Teori/Konsep, Metode (metode penelitian yang digunakan, di antaranya meliputi jenis penelitian, lokasi penelitian, sumber data, teknik pengumpulan data, pengolahan data dan analisis data.)

- PEMBAHASAN

Berisi, pembahasan terhadap masalah yang diteliti

- Analisis

Berisi analisis dari semua pokok pembahasan

- PENUTUP

Kesimpulan dan saran

Kesimpulan dan saran ditulis dalam bentuk uraian bukan dalam bentuk'angka

- DAFTAR KEPUSTAKAAN

Daftar Pustaka : ditulis berdasarkan abjad, dengan urutan : Nama pengarang. Judul buku. Kota penerbit: nama penerbit, tahun penerbitan.

Contoh ....Hamzah. Andi, Bantuan Hukum suatu Tinjauan Yuridis. Ghalia

Indonesia, Jakarta, 1983. 


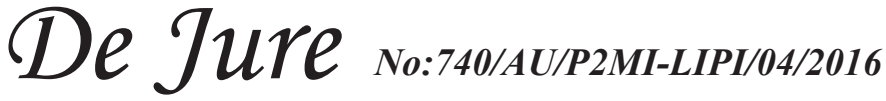

B. Naskah artikel ulasan Hasil penelitian normatif atau studi dokumenter), pemikiran dan informasi lain yang bersifat ilmiah.

o Judul aktual

Menggambarkan isi naskah dan maksimal 14 kata ditulis dalam bahasa

Indonesia dan Inggris

o Nama penulis

Tanpa gelar akademik, jabatan, kepangkatan, alamat lembaga/instansi dan e-mail

o Abstrak

Berisi Latar Belakang, Rumusan Masalah, Tujuan, Kegunaan, Metode, Isi

Pembahasan, Analisis, Kesimpulan dan Saran Temuan ditulis dalam satu spasi;

150 kata (10-30 baris/ satu (1) paragraf) diketik menggunakan huruf Times

New Roman; font 11 italic; ditulis dalam bahasa Indonesia dan bahasa Inggris

o Kata Kunci

Mengandung yang di indekskan ditulis dalam bahasa Indonesia dan Inggris

minimal 3 kata maksimal 5 kata

- PENDAHULUAN

Latar belakang masalah dan rumusan masalah

- PEMBAHASAN

Berisi, pembahasan terhadap masalah yang dikaji

- ANALISIS

Berisi analisis dari semua pokok pembahasan

- PENUTUP

Kesimpulan Dan Saran

Kesimpulan dan saran ditulis dalam bentuk uraian bukan dalam bentuk angka

- DAFTAR KEPUSTAKAAN

Daftar Pustaka : ditulis berdasarkan abjad, dengan urutan : Nama pengarang. Judul buku. Kota penerbit : nama penerbit, tahun penerbitan.

Contoh ....Hamzah. Andi, Bantuan Hukum suatu Tinjauan Yuridis. Ghalia

Indonesia, Jakarta, 1983.

5. Naskah dilengkapi dengan indeks.

6. Naskah diketik rapi 1,5 spasi di atas kertas A4; menggunakan huruf Times New Roman; Font 11; antara 20-30 halaman; diprint out dan disertai soft copy CD.

7. Penulisan kutipan sumber rujukan dengan sistem bodynote, yaitu menulisk ${ }^{\wedge} \mathrm{n}$ nama pengarang (tanpa gelar akademik); tahun penerbitan dan no halaman, yang ditulis dalam kurung; diletakan dibelakang kutipan. Contoh : .(Hamzah, 2007: 15)

8. Isi tulisan di luar tanggungjawab redaksi. Dan redaksi berhak mengedit redaksional tanpa merubah arti.

9. Naskah yang belum memenuhi syarat akan dikonfirmasikan atau dikembalikan untuk diperbaiki.

10. Keterangan lengkap dapat menghubungi redaksi Jurnal Peneltian Hukum De Jure melalui Email: jurnaldejure@yahoo.com 